\title{
Transisi Paradigma llmu dan Hukum dalam Konteks Perkembangan Hukum Indonesia
}

\author{
Sudjito dan Agus Rahardjo
}

Rasionalitas ilmu dan hukum modern, yang mangagungkan prinsip pasar dan prinsip negara, serta mengabaikan prinsip komunitas, tak pelak telah menimbulkan berbagai krisi. Demoralisasi ilmu dan hukum terjadi di seluruh lapisan kehidupan ini. IImu dan hukum modern bukan lagi menjadi tempat untuk mendapatkan jawaban atas berbagai problem sosial, tetapi justru menjadi bagian dari problema itu sendiri. Telaah ilmu dan hanya berdasarkan teori berdasarkan teori-teori fisika ala Newton, hanya berlaku pada alam animal saja, dan tidak mampu menjelaskan problema sosial yang terkait dengan manusia yang memiliki pikiran dan kesadaran serta hati nurani. Rasionalitas ilmu dan hukum modern itu, sebenarnya merupakan krisis paradigma, dan oleh karenanya hanya bisa diatasi bila lahir paradigma baru yang bertumpu pada elemen-elemen: participation, solidarity dan pleasure. Di atas ketiga elemen itulah postmodemisme harus dibangun.

Kata Kunci: ilmu hukum, moral, dan Paradigma Santos

arakteristik pandangan modernisme

dapat dilihat pada cita-cita Francois Bacon yang menginginkan manusia harus menggunakan kekuasaannya atas alam, yaitu dengan menyibak rahasia alam semesta sebanyak mungkin. Ini berarti mengangkat manusia menjadi pusat dan tolok ukur segala sesuatu atau subyektivitas individu menjadi pusat dunia.

Rene Descartes, kiranya dapat dicatat sebagai peletak dasar filsafat modernisme dengan menekankan konsep keraguan sehingga manusia harus menggunakan pikiran untuk menjawab keraguannya. Sementara itu, Issac Newton, pantas disebut sebagai perumus kerangka pikir sains untuk modernisme. la menggambarkan alam semesta sebagai sebuah mesin yang mempunyai hukum-hukum dan keteraturan, yang dapat dipahami oleh pikiran manusia.
Bagi Descartes dan Newton, manusia modern adalah makhluk otonom yang rasional yang hidup dalam dunia mekanis. Manusia yang berpikir dan dunia yang mekanis membuka jalan bagi ledakan pengetahuan di bawah panij-panji program pencerahan. Tujuan pencarian pikiran manusia untuk menyingkapkan misteri alam semesta agar manusia dapat menjadi tuan atas alam. Pencarian tersebut merupakan ciri khas modern pada abad ke dua puluh yang berusaha membawa manajemen rasional bagi kehidupan, agar melalui teknologi, kualitas hidup manusia dapat

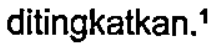

1 Uraian lebih lengkap mengenai hal ini dapat dibaca pada Stanley J. Grenz, A Primer on Postmodernism, William B. Eerdmans Publishing Co., Michigan, 1996. Diterjemahkan oleh Wilsan Suwanto menjadi Pengantar Untuk Memahami Postmodemisme, Yayasan Andi, Yogyakarta, 2001, h.10. 
Secara singkat dapat dikatakan bahwa program modernisme yang dirumuskan pada abad ke 18 melalui filsafat pencerahan terdiri atas perkembangan ilmu pengetahuan yang obyektif, moralitas dan hukum yang universal, dan seni yang otonom sesuai dengan logika internalnya masing-masing. Pada saat semua itu merupakan aktualisasi potensipotensi yang terkumpul dari bentuk-bentuk dan kegunaan mereka, yaitu organisasi rasional dari kondisi hidup dan hubungan sosial. Para penganut paham pencerahan masih berharap bahwa seni dan ilmu pengetahuan akan membantu manusia mengontrol alam, lebih dari itu mengontrol pemahaman diri dan dunia, perkembangan moral, keadilan dalam lembaga-lembaga sosial, bahkan mengontrol kebahagiaan manusia. $^{2}$

Fokus perhatian kajian ini ditujukan pada dua hal. Pertama, deskripsi pemikiran Santos tentangyang disebutnya "transisi paradigmatis ilmu dan hukum", yang di dalamnya mencakup proses historis serta transisi paradigmatis ilmu dan hukum", yang di dalamnya mencakup proses historis serta transisi paradigma modemisme menuju postmodernisme. Kedua, upaya untukmerefleksikan pemikiran Santos tersebut dalam konteks perkembangan hukum Indonesia.

\section{Dari Modernisme Menuju Postmodernisme}

Jauh sebelum Santos mengemukakan pandangan dan kritiknya, modernisme sudah mendapat serangan dan kritik tajam sejak Friederich Nietzsche pertama kali melemparkan kritiknya pada abad 19. Akan tetapi serangan tersebut belum benar-benar drastis sebagaimana yang berlangsung pada tahun 1970-an. Letupan-letupan untuk menyingkirkan modernisme secara langsung datang melalui kehadiran dekonstruksi sebagai sebuah teori linguistik yang mempengaruhi aliran baru dalam filsafat. ${ }^{3}$

Dalam pandangan santos, kita saat ini hidup dalam masa transisi paradigmatis ${ }^{4}$ antara modernisme dan postmodernisme. Pada masa transisi ini, ilmu dan hukum

2 Baca: Juergen Habermas dalam Modernity: An unfinished Project dalam The Postmodem Reader, Charles jencks (ed), New York: St. Martin's Press, 1992, h. 162-163, sebagaimana dikutip oleh Stanley J. Grenz, Ibid, h.11

3 Dekonstruksi muncul sebagai sebuah perpanjangan tangan dari teori sastra yang disebut strukturalisme. Kaum strukturalisme mengatakan bahwa bahasa adalah sebuah produk sosial dan manusia mengembangkan tulisan, teks, sebagai usaha menyusun struktur makna yang dapat memberikan makna dalam pengalaman mereka yang tidak bermakna. Filsafat postmodern menerapkan teori dekonstruksi kepada realitas. Sebagaimana setiap teks dibaca berbeda oleh orang yang berbeda, demikian juga realitas akan dibaca berbeda oleh setiap orang yang menghadapi realitas tersebut. Ini berarti tidak ada makna tunggal dalam dunia, tidak ada titik pusat dari realitas secara keselurhan. Baca: Stanley J. Ggrenz, Ibid., h. 14.

${ }^{4}$ Dalam kajian filsafat ilmu, paradigma diartikan sebagai asumsi-asumsi dasar yang diyakini ilmuwan dan menentukan cara dia memandang gejala yang ditelaahnya. Paradigma itu dapat meliputi baik "kode etik" maupun "pandangan dunia" (Weltblit), yang mempengaruhi jalan pikiran dan perilaku ilmuwan dalam berolah ilmu. Contoh paradigma sebagai kode etik ialah paradigma modern (Universalisme, komunalisme, "detachment", dan skeptisisme terorganisasi), sedangkan paradigma sebagai "pandangan dunia" misalnya tampak dalam perubahan paradigma ala revolusi keilmuan Kuhn, ketika ilmuwan beralih dari pandangan dunia mekanistik Newton ke dunia ruang Minkoski. Baca: Liek Wilardjo, Realita dan Desiderata, Dutawacana University Press, Yogyakarta, 1990, h. 134. Santos, tampaknya menggunakan pengertian paradigma dalam pengertiannya sebagai "pandangan dunia". 
mengalami krisis. Krisis ini berakar pada pilar-pilar penyangga modernisme itu sendiri. Seperti diketahui, bahwa modernisme dibangun berdasarkan pada dua pilar, yaitu pilar regulasi (the pillar of regulation) dan pilar emansipasi (the pillar of emancipation). Pilar regulasi mengarahkan pada terwujudnya perubahan dari chaos/kekacauan menuju pada keadaan yang teratur (disebut order/tatanan). Dalam pilar regulasi terkandung prinsip-prinsip negara (the principle of the state), ${ }^{5}$ prinsip pasar (the principle of market) ${ }^{6}$ dan prinsip komunitas (the principle of the community). ${ }^{7}$ Sementara itu pilar emansipasi menggariskan arah untuk terwujudnya perubahan dari keadaan tidak berpengetahuan (colonialism) menuju masyarakat yang berpengetahuan (solidarity). Pilar emansipasi itu tersusun atas tiga logika rasionalitas yang meliputi: the aesthetic-expressive rationality of the arts and literature, the coqnitive-instrumental rationality of science and technology, dan the moralpractical rationality of ethics and the rule of law. ${ }^{8}$ Dalam pandangan Santos, pilar-pilar modernisme itu sendiri secara internal mengandung hal-hal yang kontradiktif, dan secara empiris masing-masing pilar berjalan dalam relnya sendiri-sendiri, bahkan sering berlawanan satu dengan lainnya. Di satu sisi, modernisme ingin membuka cakrawala inovasi sosio kultural yang luas, tetapi pada sisi lain kompleksitas pilar-pilar penyangganya menjadikan janji-janjinya sulit terpenuhi. Santos, menyebut modernisme ini sebagai paradigma ambisius, sombong dan banyak mengobral janji. Dicontohkan, paradigma modernisme ingin mengembangkan hubungan yang harmonis dan timbal balik antara pilar regulasi dan emansipasi, sehingga bisa terwujud hubungan kooperatif antara ilmu dan hukum. Menurut santos hal inj merupakan kemunduran, setidaknya sampai ke tradisi
Giambatista Vico (1725), yang mendasarkan pada filosofi bahwa, "manusia harus dipandang sebagaimana dia adanya, dan tatanan sosial dibentuk berdasarkan perintah-perintah hukum yang bersumber pada ilmu".

Modernisme, gagal memenuhi janjinya untuk menguasai alam dan menggunakannya untuk kemashlahatan umat, dan justru membawanya kepada pemanfaatan besar-besaran dan serampangan terhadap sumber daya alam, bencana, ancaman nuklir, kerusakan lapisan ozon, dan kepada rekayasa bioteknologi dan teknis genetis, dengan konsekuensi perubahan tubuh manusia menjadi komoditas akhir.

Modernisme juga gagal memenuhi janji perdamajan abadi yang didasarkan pada perdagangan bebas dan rasionalitas ilmiah terhadap proses-proses dan lembaga pembuat keputusan. Realitanya, modernisme justru membawa ke pembangunan teknologi perang dan pertambahan persenjataaan yang belum pernah ada sebelumnya sebagai kekuatan penghancur. Menurut angka-angka yang disebut oleh Giddens, dalam abad 18 , sebanyak 4,4 juta orang mati dalam 78 perang. Dalam abad 19 , sebanyak 8,3 juta orang mati dalam 205 perang. Pada

${ }^{5}$ Prinsip ini diformulasikan oleh Hobbes. Manifestasi prinsip ini berupa hubungan vertikal antara negara dengan warga negaranya.

- Prinsip ini dikembangkan oleh Locke dan Adam Smith, prinsip ini terkait dengan hubungan antagonistik horizontal antara para partner pasar/usaha.

T Prinsip ini dikembangkan oleh Rousseau dalam teori-teori sosial dan politik. Prinsip ini mengarahkan bagi terwujudnya solidaritas horizontal antara sesama anggota komunitas atau asosiasi-asosiasi.

${ }^{3}$ Ketiga prinsip logika rationalitas ini diruntut pada pemikiran Weber. 
abad 20 , sebanyak 98,8 juta orang mati dalam 237 perang dan perhitungan belum ditutup). Antara abad ke 18 sampai 20, penduduk dunia bertambah 3,6 kali lipat, sedang banyaknya korban perang bertambah 22,4 kali.

Pada masa dua ratus tahun terakhir, hyperscientification telah mengakibatkan ketidak-seimbangan pada pilar emansipasi maupun pilar regulasi. Sejak gelombang pertama industrialisasi, kota-kota industri dan perdagangan bermunculan dan diperluas, dalam konteks kapitalisme. Perkembangan berlebihan pada prinsip pasar, ielah mengakibatkan ketidak-seimbangan pilar regulasi.

Masih banyak contoh lain dikemukakan santos untuk menunjukkan, betapa pilarpilar paradigma modernisme itu sebagai hal yang contradictive internal, tetapi sangat ambisius, sekaligus menjadi sumber permasalahan kehidupan ini.

Kegagalan paradigma modernisme dalam memenuhi ambisi dan janji-janjinya tak pelak menimbulkan berbagai ekses. Terjadilah krisi moral. Demoralisasi ilmu dan hukum terjadi di seluruh lapisan kehidupan ini. ${ }^{9}$ llmu dan hukum modern bukan lagi menjadi tempat untuk mendapatkan jawaban atas berbagai problem sosial, tetapi justru menjadi bagian dari problema itu sendiri. Sebab telaah ilmu dan hanya berdasarkan teori berdasarkan teori-teori fisika ala Newton, hanya berlaku pada alam animal saja, dan tidak mampu menjelaskan problema sosial yang terkait dengan manusia yang memiliki pikiran dan kesadaran serta hati nurani. ${ }^{10}$ Padahal, semua ilmu itu pada dasarnya terkait dengan kehidupan manusia (biasa disebut sebagai ilmu sosial). Hukum yang berlaku, lebih mengutamakan formalitas dan mengagungkan prosedur, ketimbang mencari kebenaran substantif. Pemikiran hukum sebagian besar diganti oleh pemikiran sistem, struktur, pola dan proses. Pemaknaan hukum secara kontekstual berdasarkan teori-teori mikro, diabaikan. Dalam kondisi seperti ini, muncul pertanyaan sederhana, yakni tentang a new common sense, "nilai individu dan kolektif macam apa yang harus kita ciptakan dan gunakan untuk memberi arti kepada sistem kita"?

Modernisme menyadari adanya berbagai ekses yang muncul dari krisis itu, tetapi oleh para penganutnya, ekses-ekses itu ditanggapinya sebagai hal yang bersifat temporal dan diyakini bisa ditangani secara rekonstruktif, dengan mempercayakannya pada ilmu. Akan tetapi, sekali lagi survei membuktikan, rekonstruksi ini gagal. Mengapa? Sebab (menurut Santos), ilmu memerlukan partisipasi subordinat tetapi sentral dari hukum modern. Partisipasi semacam itu sifatnya subordinat karena rasionalitas moral praktis hukum, agar efektif harus menyerah pada atau menjadi isomorfis dengan rasionalitas koqnitif instrumental ilmu. Partisipasi itu juga bersifat sentral, karena dalam jangka pendek setidaknya manajemen ilmiah masyarakat harus dijamin terhadap oposisi dan integrasi normatif yang diberikan hukum. Dengan kata lain, depolitisasi ilmiah terhadap kehidupan sosial akan dicapai lewat depolitisasi yuridis terhadap konflik-konflik sosial.

${ }^{9}$ Menurut Satjipto Rahardjo, justru inti huum itu terletak pada moralitas. Apabila hukum sudah dilepaskan dari unsur moralitas, seperti keadilan, kejujuran, kebenaran dan nilai-nilai mulia lainnya, maka ia hanyā zombie. Baca: Satjipto Rahardjo, Indonesia Inginkan Penegakan Hukum Progresif, Kompas, 19/9/2002.

${ }^{10}$ Baca: Liek Wilardjo, op. cit, h. 211. 
IImu dan hukum modern telah dikonstruksi melalui rasionalitas (sebagaimana pernah terjadi antara abad 16-19), dan oleh karenanya menjadi bertentangan dengan akal sehat (yang emansipatif) serta kehilangan ruhnya. IImu dan hukum modern menjadi tak bermoral. Masing-masing berjalan sendiri-sendiri, sehingga tak mungkin mampu merekonstruksi berbagai ekses yang disebutkan di atas. Pada gilirannya kita saksikan rasionalitas itu telah mengabaikan komunitas dan menjadi penjajah prinsip pasar dan negara.

Dalam pandangan santos, rasionalitas ilmu dan hukum modern itu merupakan krisis yang besar yaitu krisis paradigma, dan oleh karenanya hanya akan bisa diatasi bila lahir paradigma baru. Dengan mengutip pendapat Saint-Simon, dikatakan bahwa krisis itu hanya bisa diatasi dengan "agama" baru; dan "agama" baru itu adalah ilmu (Science). Akan tetapi, Santos sendiri tampak skeptis, kapan paradigma ilmu dan hukum baru itu akan lahir. Keraguannya itu bertumpu pada realita bahwa sampai saat ini kita masih berada pada masa transisi, dari revolusi ilmiah relativisme Einstein menuju pada teori-teori fisika quantum (yang cenderung pada pendekatan etnosentrisme), dan kita tak tahu kapan hal ini akan berakhir. Santos menawarkan penyelesaian melalui konsep double epistemoglogical break. Dengan konsep ini, ilmu semasa modernisme harus diputuskan dengan ilmu pada masa setelah modernisme, dalam rangka mewujudkan akal sehat memerdekakan diri.

Menurut Santos, bagaimanapun juga, kita perlu mencari paradigma kehidupan baru yang layak, yang bertumpu pada tiga elemen, yaitu partisipasi (Participation), solidaritas (solidarity), dan kebahagiaan (pleasure). Inilah yang disebutnya paradigma postmodernisme.
Permasalahannya bagaimana kita bisa melampaui kapitalisme, sebagai model produksi yang sangat berkuasa di abad ini? Seperti kita sadari, pemikiran, pendapat, kaidah-kaidah, praktik dan tradisi kapitalisme telah berurat berakar dalam semua segi kehidupan, sehingga merusak makna kehidupan sosial, politik, hukum, budaya sampai dengan agama. IImu dan hukum modern di sini sudah cenderung dilepaskan keterikatannya dengan paradigma moral, dan lebih terikat pada paradigma politik atau paradigma ekonomi. Dalam pandangan kapitalis, hak milik adalah penting sebagai sarana eksploitasi dan sekaligus merupakan sumber kehidupan. Tak pelak lagi, siapa yang menguasai sumber daya alam akan memperoleh kesempatan luas untuk berkuasa. Dekonstruksi hukum, bagi kapitalis diyakini tidak akan mampu melahirkan perubahan-perubahan sosial, sebab hukum tiada lain merupakan sarana pra kapitalis. Perubahan sosial, menurutnya hanya dimungkinkan dengan revolusi.

Menurut Santos, langkahnya harus diawali dengan keberanian melakukan self critique di dalam epistemologis maupun ilmu dan hukum modern itu secara radikal. Melalui self ciritique ini, akan memudahkan kita memahami permasalahan-permasalahan ilmu dan hukum modern, dan secara perlahan-lahan menetralisirnya menjadi potensi emansipatif. Dimensi epistemologi ilmu dan hukum akan bisa diketemukan apabila kita mencari akarnya pada masalah sosial kita sendiri. Di sinilah, keharusan adanya kritik epistemologi yang hegemoni dan keharusan menciptakan ilmu dan hukum yang baru itu. Upaya seperti ini, menurut Santos merupakan bentuk pengadilan terhadap ciri-ciri paradigma yang baru yang muncul maupun ciri-ciri akal sehat yang emansipatif. 
Paradigma postmodernisme, juga tak lepas dari tradisi seperti itu, artinya, pada setiap paradigma akan selalu dijumpai berbagai keterbatasan, dan oleh karenanya tidak mungkin bisa menjawab semua persoalan kehidupan dengan baik. Permasalahan kehidupan ini pasti akan terus ada dan tak terselesaikan.

\section{Perkembangan Hukum di Indonesia}

Perkembangan hukum di Indonesia yang terjadi saat ini sebenarnya terkait erat dan tak bisa dilepaskan dari sejarah perkembangan hukum di negeri Belanda maupun sejarah berdiri dan berkembangnya negara Indonesia. Abad 19, bagi negaranegara di Eropa merupakan masa gemilang, yang ditandai dengan peningkatan kesejahteraan dan kemakmuran masyarakat di mana individu sebagai pusat pengaturan hukum. Kegemilangan itu dilatarbelakangi oleh semangat kemerdekaan individu yang berakar dari revolusi Perancis dengan siogan leberty, egality dan fraternity. Filosofi itu berimbas pada dunia hukum dimana individu begitu dihormati dan dihargai. Semangat dan paham ini untuk selanjutnya diusahakan disebarluaskan dengan cara penaklukan atau penjajahan pada negara-negara lain.

Indonesia sebagai negara jajahan Belanda tak dapat melepaskan diri dari proses transplantasi hukum Belanda. Di samping itu, politik hukum pemerintah Kolonial Hindia Belanda menerapkan asas konkordansi dan asas ketunggalan hukum (een heidsbeginsel), dalam bentuk penyusunan kodifikasi dan unifikasi KUH Perdata, KUH Dagang dan KUH Pidana merupakan asas-asas politik hukum yang mengemuka pada abad ke 19, bahkan berlangsung pasca Kolonial Hinda Belanda. ${ }^{11}$

Dengan perkembangan hukum seperti di atas, otomatis jenis hukum yang ber- kembang (dan juga diajarkan pada pendidikan hukum) saat itu berupa hukum modern dengan karakteristik sebagai berikut: ${ }^{-2}$

a. Hukum modern terdiri berbagai aturan yang diterapkan dengan cara uniform dan konsisten,

b. Perundang-undangan modern bersifat transaksional,

c. Norma-norma hukum modern adalah universalistis,

d. Sistemnya adalah berjenjang/hirarkis,

e. Sistem ini diatur secara birokratis,

f. Sistem hukum modern bersifat rasional

g. Sistem ini dijalankan oleh para ahli hukum sendiri yang khusus belajar profesional,

h. Sistem ini lebih bersifat teknis dan kompleks,

i. Sistem ini dapat diubah pada aturan dan prosedur guna menghadapi kebutuhan-kebutuhan yang berubah,

j. Sistem hukum modern bersifat politis, k. Legislatif, eksekutif dan yudikatif terpisah dan berbeda jelas.

Terkait dengan ciri-ciri hukum modern seperti di atas, maka ilmu hukum yang berkembang adalah ilmu hukum dalam pengertian ius, diantaranya ius constitutum yang terbentuk dalam negara dan pertu ada kepastian hukum. lus ini memiliki dua

"Tentang bagaimana proses transplantasi hukum kolonial ke hukum nasional ini dapat dilihat lebih jelas dan lengkap pada Soetandyo Wingjosoebroto, Dari Hukum Kolonial ke Hukum Nasional, Dinamika Sosial-Politik dalam Perkembangan Hukum di Indonesia, Rajawali Press, Jakarta, 1994.

${ }^{12}$ Marc Galenter, The Modemitization of Law, dalam Modemization: The Dynamics of Growth, Voice of America Forum Lectures,sebagaiman dikutip oleh Wukir Prayitno, Modernitas Hukum Berwawasan Indonesia, CV. Agung , Semarang, 1990, h. 12 
model. Pertama, model Perancis yang dibentuk oleh Legislatif sebagai wujud dari trias politiknya Montesqiue yang berkembang di Perancis saat itu, sehingga disebut confinental/civil lay system. Kedua, model anglo saxon/common law system yang membentuk yudisial yakni hakim dan lawyer. Sedangakan teori (doktrin) hukum yang terkemuka hingga sekarang (abad 20 dan awal abad 21) berasal dari teori (doktrin) hukum Hans Kelsen, dapat dicontohkan dengan masih menguatnya aliran positivisme. ${ }^{13}$

Pemikiran tentang hukum yang kemudian melahirkan positivisme, tak dapat dipisahkan dari kehadiran negara moden. ${ }^{14}$ Ciri khas dari aliran positivisme pada hukum modern ini bertitik temu pada formalitas, ${ }^{15}$ yang berlandaskan pada obyek real dan berangkat dari deduksi dengan kekuatan logika telah mendapatkan tempat yang signifikan pada kajian teori hukum. Hukum dipandang sebagai suatu institusi yang otonom dan murni agar memiliki kekuatan sah dan mampu berlaku, maka tak boleh dan tak akan dicampuri oleh aspek non hukum baik politik, ekonomi, sosial bahkan moralitas. ${ }^{16}$ Teori hukum positivistik berlatar belakang pada leberalisme yakni menjunjung tinggi pada kemerdekaan individu maka perlindungan hukum individu penting untuk diutamakan yang memunculkan rule of law. ${ }^{17}$

Hukum Indonesia yang masuk dalam kategori hukum modern itu ternyata tak dapat menyelesaikan persoalan-persoalan yang muncul pada era 1980 sampai 1900an. Dengan mendasarkan pada apa yang dikemukakan Santos, ketidakmampuan hukum dalam menyelesaikan masalah berkaitan dengan ketidakseimbangan pilar penyangga modernisme. Pilar regulasi mengalami ketidakseimbangan pada prinsip negara dan prinsip pasar dibandingkan dengan prinsip komunitas. Prinsip negara yang didalamnya terkandung kekuasaan pemerintah terlalu dominan berkuasa dan prinsip pasar yang didorong maju melalui konglomerasi yang didukung oleh birokrasi. Prinsip negara dan prinsip pasar berpadu menjadi satu, sehingga mereka yang memiliki kekuasaan (dalam hal ini penguasa atau pejabat) juga terjun ke dalam bisnis. Dua prinsip itu maju ke depan, sedangkan prinsip komunitas ditinggalkan sehingga masyarakat sering menjadi korban dari kredo modernitas, yaitu pembangunan.

Kondisi hukum Indonesia yang seperti itu diistilahkan oleh Dato Param Cuma-

13 Oleh Roberto Mangabeira Unger disebutkan bahwa masyarakat abad 20 dan 32 sebagai masyarakat pasca liberal yang masih kental dengan hukum modernnya Roberto M Unger, Law In Modem Society Toward a Critism of Social Theory, Collier Macmillan Publisher, London, 1976.

${ }^{14}$ Satjipto Rahardjo, Rekonstruksi Pemikiran..., op. cit., h. 4

${ }^{15}$ Formalitas menurut Unger berarti tanda-tanda yang membedakan suatu sistem hukum: usaha untuk suatu hukum yang general, otonom, publik dan positif. Roberto M. Unger, op. cit., h. 203

${ }^{15}$ Dengan kata lain menurut Hans Kelsen, suatu teori hukum yang murni harus bersih dari politik, etika, sosiologi, sejarah. Tugasnya ialah untuk mengetahui semua yang essensial dan perlu untuk hukum, dan oleh karena itu bebas dari segala sesuatu yang berubah dan kebetulan, W. Friedman, Teori dan Filsafat Hukum Telaah Kritis atas Teori-teori Hukum (Susunan I), Raja Grafindo, Jakarta, 1993, h. 169.

17 Menurut bahasa supremasi hukum berasald ari kata supreme mempunyai arti kekuasaan tertinggi (teratas), sedangkan hukum berarti peraturan. Supremasi hukum berarti suatu peraturan yang tertinggi, $H$. Harris Soche, Supremasi Hukum dan Prinsip Demokrasi di Indonesia, Hanindita, Yogyakarta, 1985, h. 5 
raswamy ${ }^{18}$ disebut sebagai "kebusukan hukumn. Dikatakan bahwa kondisi hukum Indonesia dalam keadaan kritis dan parah karena sudah meliputi kultur baik internal yaitu aparat penegak hukum besera filosofi peraturan produk perundangan maupun kultur eksternal yaitu masyarakat luas. Selain itu dikatakan bahwa sistem hukum Indonesia adalah salah satu yang terburuk di dunia, sehingga butuh waktu tahunan untuk memperbaikinya karena terkesan persoalan hukum dibiarkan saja. Penilaian dari Cumaraswamy diperkuat pula hasil jajak pendapat bulan Juni 2003 lalu dari Political Economic Risk Consultancy (PERC) bahwa sistem peradilan dan kepolisian di Indonesia termasuk yang terburuk di Asia, skornya 9,83 dengan nilai terburuk 10 .

Kegagalan hukum modern dalam menyelesaikan persoalan di Indonesia disebabkan karena hukum modern lebih memperhatikan perlindungan kemerdekaan individu daripada sebagai pengantar keadilan. ${ }^{19}$ Tak heran apabila pada hukum modern yang diutamakan struktur yang jelas, prosedural dan rigid. Ciri instrumental dari hukum modern yaitu peng-gunaanya dengan sengaja untuk mengejar tujuantujuan atau untuk mengantarkan keputusankeputusan politik, sosial, dan ekonomi yang diambil aleh negara. ${ }^{20}$

Disadari atau tidak, perkembangan hukum di Indonesia saat ini telah terjebak pada konsep hukum para profesional yang disebut "lawyer's law, "law for the lawyers" atau "law for the profesionals". Konsep hukum ini, lahir dari pemikiran kaum positivis, yang hanya mau mengakui kebenaran itu pada hal-hal yang pasti, bisa dibuktikan, dan bisa diterima akal (logika); sebaliknya semua hal-hal yang serba metafisik dan teologis dinafikan. Konsep hukum ini mulai dikenal sekitar abad 18, dan kini telah merambah dan mendominasi perkembangan hukum seluruh dunia (termasuk Indonesia). Sedemikian kuatnya dominasi aliran positivisme ini, sehingga seolah-olah tidak ada hukum (perundangundangan) di luar yang telah dipositifkan itu. Hukum positif (tertulis dan terkodifikasi) dipandang sebagai ciri hukum modem. Inilah yang disebut hukum negara, yang dalam tatanan yang lebih besar, ia termasuk ke dalam tatanan politik. ${ }^{21}$

Hukum (tatanan) memang harus berubah dan berkembang dari waktu ke waktu. Kendati hukum sebagai tatanan politik itu sekarang dominan, tidak berarti hukum dalam ranah tatanan transendental maupun tatanan sosial tidak ada. Cuma saja, hukum dalam ranah kedua tatanan yang disebut terakhir itu, selalu dipinggirkan. Inilah yang mengakibatkan hukum tidak mampu menjelaskan apa yang terjadi di masyarakatnya dengan baik. Dalam konteks ini, maka pemihakan hukum secara ekstrem pada tatanan politik, identik dengan penegakan pilar regulatifrasiona! tetapi mengesampingkan pilar emansipatif-moral, sebagaimana dikemukakan Santos. Inilah salah satu bentuk demoralisasi hukum yang tengah berlangsung di negeri ini.

Kita semua tentu merasa "gerah" dengan situasi, proses, maupun kondisi

${ }^{18}$ Dato Param Camaraswany adalah utusan khusus PBB berlatarb belakang pengacara kelas dunia asal Malaysia yang telah berpengalaman dan berkomitmen besar terhadap penegakan hukum yang bersih. Lihat komentarnya dalam Waming dari Cumaras-wamy, Republika, Kamis 25 Juli 2002, Jakarta. H. 5

${ }^{19}$ Satjipto Rahardjo, Supremasi Hukum yang Benar, Kompas , 6 Juni 2002.

${ }^{20}$ Wukir Prayitno, op. cit., h. 39

21 Baca: Satjipto Rahardjo, Mengajar Keteraturan Menemukan Ketidak-teraturan, Fakultas Hukum UNDIP, Semarang, 2000, hl. 7-8. 
penegak hukum. Beragai bentuk kekecewaan itu, tampaknya masih berkutat pada paradigma lama (positivisme), walau-pun "angin" keinginan untuk menapak pada paradigma baru terus dihembuskan. Hal ini mengindikasikan bahwa pergeseran garis ilmu (hukum) harus terus didorong. Kebenaran ilmu (hukum) jangan terpaku pada halhal yang pasti, positif, dan bisa dibuktikan akal-pikiran saja, tetapi harus mampu menjangkau pada kebanaran-kebanaran substantif lain yang eksis di dalam masyarakat. Sistem atau penyelenggaraan hukum seharusnya diarahkan untuk mendapatkan kebenaran itu, dan bukan mencari kemenangan sebagaimana proses peradilan yang berlangsung selama ini. ${ }^{22}$ Upaya-upaya mengkonsepkan penegakan hukum progresif itu, bisa diidentikkan dengan pergeseran era Newton menuju era Teori Quantum, sebagaimana dijelaskan oleh Santos di atas.

Di era teori Quantum, self critique terhadap paradigma tetap dan harus dimunculkan. Hal ini terutama pada penggunaan IQ (Intellectual Quotient) yang selama ini menjadi andalan untuk mengukur kecerdasan seseorang. Janganlah berpretensi bahwa dengan pergeseran paradigma, menjadikan permasalahan-permasalahan sosial bisa dijelaskan dan diatasi keseIuruhannya dengan baik. Dalam pandangan Danah Zohar dan lan Marshall, hanya dengan komplementaritas, antara IQ dan SQ (Spiritual Quotient), maka seseorang bisa mencapai puncak pemahaman, yaitu sampai konteks-makna. Ini pula yang menurut Satjipto Rahardjo dipandang sebagai tingkat pembelajaran yang paling tinggi, juga dalam bidang hukum. ${ }^{23}$

Kita menggunakan SQ untuk berhadapan dengan masalah eksistensial yaitu saat kita secara pribadi merasa terpuruk, terjebak oleh kebiasaan, kekhawatiran dan masalah masa lalu akibat dan kesedihan.
SQ menjadikan kita sadar bahwa kita memiliki masalah eksistensial dan membuat kita mampu mengatasinya atau setidaktidaknya berdamai dengan masalah tersebut. SQ memberi kita semua rasa yang "dalam" menyangkut perjuangan hidup. SQ adalah pedoman saat kita berada di "ujung". Masalah-masalah eksistensial yang paling menantang dalam hidup berada di luar yang diharapkan dan dikenal, di luar aturan-aturan yang telah diberikan, melampaui masa lalu, dan melampaui sesuatu yang kita hadapi. ${ }^{24}$

\section{Penutup}

Fenomena postmodern, merupakan indikasi berakhirnya sebuah cara pandanga universal. Etos Postmodern menolak penjelasan yang harmonis, universal dan konsisten. Postmodern menolak adanya realitas yang utuh sebagai obyek dari persepsi kita. ${ }^{25}$ Mereka menggantikan

22 Satjipto Rahardjo, Indonesia Butuh Keadilan yang Progresif, Kompas, 12/10.2002 h. 13

${ }^{23}$ Satjipto Rahardjo, Mengejar ....., op. cit.,

${ }^{24}$ Dalam teori kekacauan (chaos), "Ujung" adalah perbatasan antara keteraturan dan kekecauan, antara mengetahui diri kita dan sama sekali kehilangan jati diri. "Ujung" adalah suatu tempat bagi kita dapat menjadi kreatif. $S Q$, pemahaman kita yang dalam dan intuitif kita akan makna dan nilai merupakan petunjuk bagi kita saat berada di "ujung". SQ adalah hati nurani kita. Baca: Agus Nggermanto, Quanfum Quotient (Kecerdasan Quantum), Nuansa, MUC, Yayasan Quantum, ZQTC, Bandung, 2001 , h. 141 - 142.

${ }^{25}$ Cara pandang modern beranggapan bahwa realitas terstruktur dan rasio manusia dapat mengetahui struktur hukum-hukum alam. Ini merupakan atau sebagai akibat pengaruh pandangan deterministik Newtonian yang berpengaruh terhadap cara pandang modern termasuk pada bidang hukum. 
semua ini dengan sikap hormat kepada perbedaan dan penghargaan kepada yang khusus (partikuler dan lokal) serta membuang yang universal. Postmodernisme menolak penekanan kepada penemuan ilmiah melaluj metode sains, yang merupakan fondasi intelektual dari modernisme untuk menciptakan dunia yang lebih baik. Pada dasarnya postmodernisme adalah anti modem.

Transisi menuju postmodern kini juga melanda Indonesia, khususnya dalam bidang hukum. Narasi besar yang selama ini ada sebagai produk modernisme yaitu positivisme mulai digugat, setidak-tidaknya pada tingkat teoritis. ${ }^{26}$ Pada tataran praktis positivisme masih dominan sebagaimana halnya teori fisika Newton yang secara teoritis sudah lengser, akan tetapi secara praktis masih berakar dan banyak dipakai orang.

Kita setuju bahwa pada masa transisi paradigma ilmu dan hukum dari modernisme ke postmodernisme, banyak permasalahan sosial yang tak terselesaikan. Kalaupun lompatan paradigma ala Kuhn bisa dilakukan oleh ilmuwan, permasalahan sosial pasti tetap akan bermunculan, dan tidak semuanya terjawab dengan baik.

Kitapun setuju bahwa kapitalisme, telah menjadi "perusak" bagi perkembangan ilmu dan hukum. Dia berkembang dengan pesat ketika ilmuwan maupun para juris lebih mengedepankan rasio ketimbang hati nurani. Demoralisasj ilmu dan hukum menjadi bagian kehidupan ini,tetapi akankah kita menyerah?

Dalam situasi transisi ini, kita butuh lompatan paradigma. Elemen-elemen participation,solidarity and pleasure, sebagaimana disarankan Santos, memang penting, akan tetapi tak kalah pentingnya adalah komplementaritas antara IQ dan SQ (yang disandarkan pada nilai-nilai religius). Inilah cakupan paradigma baru yang kita inginkan.

Kita tentu sependapat dengan apa yang dinyatakan Achmad Ali, ${ }^{27}$ bahwa kita harus bejuang agar hukum dapat dikembalikan pada akar moralitasnya, akar kulturalnya dan akar religiusnya, sebab hanya dengan cara itu, masyarakat akan merasakan hukum itu cocok dengan nilai-nilai instrinsik yang mereka anut. Sepanjang aturan hukum yang ada tidak sesuai dengan nilai-nilai intrinsik warga masyarakat, maka ketaatan hukum yang muncul hanyalah sekedar ketaatan yang bersifat complience (taat hanya karena takut sanksi), dan bukan ketaatan yang bersifat internalzation (taat karena benarbenar menganggap aturan hukum itu cocok dengan intrinsik yang dianutnya).

\section{Daftar Pustaka}

Ali, Achmad. Gara-gara "Syariat" Belanda: Terkorup di Dunia, tapi 'Tak Ada' Koruptornya, Suara Hidayatullah, edisi khusus, 10/XV/ Mei/ 2002

Friedman, W. 1993. Teori dan Filsafat Hukum Telaah Kritis atas Teori-teori Hukum (Susunan ), Jakarta:Raja Grafindo.

Grenz, Stanley J.1996. A Primeron Postmodernism, William B. Eerdmans Publishing Co., Michigan diterjemahkan oleh Wilson Suwanto,2001. Menjadi, Pengantar Untuk Memahami Postmodernisme, Yogyakarta: Yayasan Andi.

${ }^{26}$ Lihat penjelasan dari gugatan terhadap positivsme ini pada Satjipto Rahardjo, Rekonstruksi Pemikiran Hukum....., op. cit., h. 14.

${ }^{27}$ Achmad Ali, op. cit., h. 21 
Nggermanto, Agus.2001. Quantum Quotient (Kecerdasan Quantum), Nuansa, MUC, Bandung:Yayasan Quantum, ZQTC.

Prayitno, Wukir. 1990. Modernitas Hukum Berwawasan Indonesia, Semarang: CV.Agung.

Rahardjo, Satjjpto. 2000.Mengajar Keteraturan Menemukan Ketidakteraturan, Semarang:Fakultas Hukum UNDIP.

Kompas,Indonesia Butuh Keadilan yang Progresif,12/10/2002

Kompas, Indonesia Inginkan Penegakan Hukum Progresif,, 19/9/2002

Rekonstruksi Pemikiran Hukum di Era Reformasi. Makalah pada seminar nasional menggugat pemikiran positivisme di Era Reformasi, Program Doktor UNDIP. Semarang 22 Juli 2000.

Santos, boaventura De Sousa.1995. Toward a New Common Sense - Law, Sci- ence and Politics int The Paradigmatic Transition.New York: Routledge.

Soche,H. Harris. 1985. Supremasi Hukum dan Prinsip Demokrasi di Indonesia,Yogyakarta:Hanindita.

Sugiharto, I. Bambang. 1996. Postmodernisme, Tantangan Bagi Filsafat, Yogyakarta:Kanisius.

Unger, Roberto M, 1976. Law In Modem Society Toward a Critism of Social Theory, London:Collier Macmillan Publisher.

WignjoSoebroto, Sotandyo. 1994. Dari Hukum Kolonial ke Hukum Nasional, Dinamika Sosial-Politik dalam Perkembangan Hukum di Indonesia, Jakarta:Rajawali Press.

Wilardjo, Liek, Realita dan Desiderata.1990. Yogyakarta:Dutawacana University Press. 